\title{
Fostering Positive Listening Habits among EFL Learners through the Application of Listening Strategy and Sub-skill Instructions
}

\author{
Hoang Huy Nguyen \\ University of Languages and International Studies, Vietnam National University, Hanoi, Vietnam
}

\begin{abstract}
The article presents a research project carried out at University of Languages and International Studies, Hanoi, on the integration of explicit listening strategy and sub-skill instructions into listening lessons. A strategy and sub-skill integrated syllabus was devised and implemented in eight consecutive weeks. The research aimed at investigating how students improved their listening habits after being taught listening strategies and sub-skills explicitly, as well as their engagement with and perception of this new teaching method. Data were collected via individual interviews, observations, and narrative frames. The results revealed some positive effects of the intervention on students' listening skills and habits: students knew to use strategies in listening, which led to the acquisition of listening sub-skills and improvement in their listening comprehension. Factors affecting students' engagement with and their perceptions of the new teaching method were also substantially explored. Based on the findings, relevant pedagogical implications were proposed with the aim of equipping English teachers with practical guidelines on how to integrate explicit strategy and subskill instructions into their listening classes.
\end{abstract}

Index Terms - listening habits, listening strategy, sub-skill instructions

\section{INTRODUCTION}

\section{A. Rationale for the Study}

Listening used to receive little attention from scholars in the not so distant past (Siegel, 2011). It was once regarded as a passive skill, or a tool to introduce grammar and vocabulary items (Field, 2008). However, the simultaneity and spontaneity of listening makes it an inherently important, and at the same time, difficult skill to master. Listening usually takes place "in real time" (Helgesen, 2003, p. 24; Field, 2008; p.38, Renandya, 2012, p. 6), which means that the listener must comprehend the aural input the moment it is uttered. As a result, she/he hardly has time to spare for reviewing and looking up new words. Being aware of this, scholars and teachers have recently reexamined the position of listening in language learning. They now acknowledge listening as an active process (Vandergrift, 2004) that should be entitled to a distinctive set of developmental principles (Rubin, 1994). Listening comprehension is currently perceived as one of the central activities in the second language (L2) classroom (Vandergrift, 2007).

Along with changes in teachers' and scholars' perceptions of the role of listening, approaches to teaching this skill have also been under review. However, this review process is slow, and not much change has taken place since the 1960s (Field, 2001, 2008). Many of the methods currently applied in teaching listening are believed to have been transferred from the earlier developed reading skill (Field, 2001). As a result of too much emphasis on a exercise completion, the core steps of teaching listening remains unchanged throughout the course of half a century with three main stages: pre-listening, listening (including both extensive listening for general ideas and intensive listening to answer comprehension questions), and post-listening. The alterations take place only inside each stage. For example, in the post-listening stage, instead of pausing a recording to let students repeat after it, the teacher may now help students to scrutinize functional languages and deduce vocabulary meaning from contexts.

One of the most popular models of today's listening lesson is based on the Comprehension Approach (CA) (Field, 2001, 2008). The CA approach to teaching listening is based upon the assumption that students would develop their listening skill by getting maximal exposure to the spoken form of a language. Some of the discernible strengths of this approach to teaching listening involve the fact that this way of teaching enables learners to get high results in exams (Field, 2008). Stakeholders of language tests are often subscribed to the CA when operationalizing their tests, as it ensures the high reliability, although this form of test does not always accurately reflect learners' true competence. Another benefit of the CA is related to the nature of listening ability, which is that listening improves with exposure. When listening to a spoken language, learners will undergo several processing steps before they finally comprehend the message. They will become more successful when they can internalize the steps, and the CA will provide them with an abundance of chances to practice doing so.

However, the CA is not without criticism. As observed by Lynch (2009), this approach puts too much emphasis on the testing conditions and students' memory. This is the reason why the comprehension approach is also known as the 
test-oriented approach (Sobouti \& Amiri, 2014): the teacher plays the recording several times for the students to answer comprehension questions without teaching them how to listen (Mendelsohn, 2006). This test-oriented approach is usually favored by more proficient students, but might not be very helpful for students at lower levels, who can even be disheartened as they cannot see any progress (Field, 2008). Other weaknesses of the CA include its inherent advocacy of a teacher-centered classroom, and its inability to inform teachers of how and why learners perform well or badly in solving listening comprehension problems.

One of the most recent approaches to teaching listening more effectively involves incorporating direct instructions of listening strategies (LS) into the lesson. This is known as the Strategy Approach (Field, 2000). Oxford (1990, p.8) defines strategies as "specific actions taken by the learner to make learning easier, faster, more enjoyable, more effective, and more transferrable to new situation". The effectiveness of a strategy-based syllabus has been the target of research by several scholars (Carrie, 2003; Graham \& Macaro, 2008; Vandergrift \& Tafaghodtari, 2010; Sotoudeh, 2013).

A sub-skills approach (SS approach) (Field, 2008) is another attempt to find effective ways to teach listening. It involves first identifying the "target behavior" (p.98) that is associated with a person who has mastered the listening skill (in this case, a native speaker), and then breaking down that "target behavior" into a range of abilities, or sub-skills. The underlying assumption is that in order to be good at a language skill, the learner must acquire as many of the subskills, as possible. This approach would enable the teacher to actually teach students to listen instead of just providing them with chances to listen.

At University of Languages and International Studies (ULIS) in Hanoi, where this research project took place, language teachers widely adopt the CA in teaching listening. This way of teaching listening, as discussed above, is of great benefit to senior students, who are expected to take a language proficiency test at level $\mathrm{C} 1$ in the Common European Framework of Reference for Languages (CEFR) by the end of the second academic year (Semester 4). The CA can simulate the atmosphere in test rooms, and thus, familiarize the students with test-taking procedures. However, first-year students would not benefit much from this way of teaching listening, as their listening skills have not been fully developed due to a chronic lack of listening lessons at almost high schools in Vietnam. With a view to enhancing the listening skill of first-year students at ULIS, the researcher tried to incorporate explicit instructions of both listening strategies and sub-skills into his lessons.

\section{B. Research Objectives and Research Questions}

This action study consisted of an eight-week teaching project conducted to innovate the teaching and learning of EFL listening at Division 1, Faculty of English Language Teacher Education, ULIS. Specifically, the researcher wanted to gain insights into changes in the ways first-year EFL learners at ULIS approached and solved listening comprehension problems, hereafter referred to as their listening habits, after receiving explicit instructions of LS and SS from their teacher. Particular attention was directed towards students' application of the taught LS and SS both inside and outside the classroom environment. In addition, the researcher attempted to examine students' perceptions of the effectiveness of the LS and SS taught in the project, as there has been little research on the approach combining both LSs and SSs into the lessons, despite the potential benefits it can bring to students' listening comprehension (Goh, 1998).

In summary, this qualitative study aimed at (1) identifying the changes in students' listening habits after the integration of listening strategies and sub-skills into the syllabus; and (2) exploring students' perceptions the effectiveness of and the correlation between the listening strategy and sub-skill instructions. Subsequent to answering fulfilling these targets, ways to improve the effectiveness of the intervention and relevant pedagogical implications were also considered. The abovementioned objectives can be formulated into the following research questions:

1. What changes occur in students' listening habits after they received explicit listening strategy and sub-skill instructions?

2. How do students perceive the effectiveness of the listening strategies and sub-skills integrated method employed in the project?

\section{LITERATURE REVIEW}

\section{A. Listening Sub-skills}

Listening should not be regarded as "a monolithic skill but as a complex of many contributory abilities or sub-skills" (Field, 2008, p. 98). Field (1998) defines sub-skills as the abilities mastered by native speakers that L2 learners must possess in order to learn a language. Richards (1983) is among the first to come up with a comprehensive taxonomy of listening sub-skills Despite its inclusiveness, Richards's (1983) taxonomy has not received much attention from teachers and textbook designers (Field, 1998, 2008).

Rost's taxonomy (1990) goes one step further than Richard's taxonomy (1983) in that it groups sub-skills into clusters based on the theory about the cognitive process involved in listening. Lynch (2009) comments on Rost's taxonomy as "simpler and more manageable" (p. 32) and more suitable for classroom instruction. However, Rost himself could not avoid the pitfall of indirectly suggesting an order of acquisition for listening sub-skills. 
Several implications for teachers who intend to subscribe to the sub-skills approach to teaching listening can be made from Rost's arguments. Firstly, teachers should not teach one sub-skill individually. Instead, they should identify subskills that are related to each other to include in a lesson. Secondly, the practice of sub-skills should not be separated from meaningful contexts. If teachers emphasize too much on the development of certain sub-skills and neglect other aspects of listening, their students will suffer. Thirdly, it is still inconclusive as to which sub-skills language learners should acquire first (Rost, 1990). Thus, teachers should be flexible in selecting and arranging sub-skills to include in the syllabus.

\section{B. The Sub-skills Approach to Teaching Listening}

The sub-skills approach to teaching listening is developed to help make it easier for students to (1) transfer the listening sub-skills they already have in their native language into their second language, and (2) at the same time develop new ones. This approach was constructed around three essential assumptions: (1) there are listening sub-skills and they can be identified; (2) learners can practice those sub-skills independently of each other; and (3) learners can combine those individual sub-skills to improve their listening comprehension. It follows that if a learner wants to master listening skills, he/she should possess as many of those sub-skills as possible and know how to employ a number of them simultaneously. In this approach to teaching listening, a teacher would have students listen to a series of (usually short) listening passages and then do several tasks in order to develop only one, or a certain cluster of sub-skills (Field, 2008; Richard, 1983; Rost, 1990).

According to Field (2008), when applying the sub-skills approach, teachers are actually teaching listening instead of merely creating chances for students to listen. Moreover, teachers have one more method to make the listening activity a progressive one in addition to just choosing longer and faster input: they can devise tasks to help their students acquire simpler sub-skills first and more difficult ones later.

\section{Listening Strategy Taxonomy}

Vandergrift's (1997) descriptive research into listening strategies of (French) learners can be regarded as one of the pioneers in listening strategies. This taxonomy of listening strategies, developed from the work of O'Malley and Chamot (1990) and Oxford (1990), paves the way for other researchers, and has been cited in many studies (e.g. Cross, 2009). There are three categories of strategies in total: metacognitive, cognitive, and socio-affective strategies.

Metacognitive strategies, which are "mental activities for directing language learning" (Vandergrift, 1997, p. 391), are divided into four types of sub-strategies: planning, monitoring, evaluation, and problem identification. Metacognitive strategies involve thinking about the way information is processed and stored, and taking appropriate steps to manage and regulate these cognitive processes.

Cognitive strategies, which concern mental activities for controlling the language to accomplish a task, comprise 11 main strategies.

Socio-affective strategies, consisting of five sub-strategies, are those activities related to interacting with other people and controlling the affective side of language learning.

\section{The Good Language Learner and Strategy Use}

Some people learn languages more quickly than others (Lightbown \& Spada, 2005), and the rate of acquisition of not only L2 and FL, but also L1 "varies widely" (p. 54) among learners. Moreover, Lightbown and Spada (2005) mention the fact that in some language classes, while some learners make great progress over a short period of time, others have to struggle over a much longer span in order to accomplish the same objectives. Many early studies in the field of SLA aimed at seeking an answer to the questions "What makes a good language learner?" and "What can we learn from them?". Overall, the similar picture of a good language learner shared by all previous studies (Rubin, 1975; Naiman et al., 1978; Lightbown \& Spada, 2005; Griffiths, 2004) is someone who participates in language learning actively and is capable of solving problems regarding their own learning. In short, there is sound empirical evidence to suggest that there are certain differences in strategy use patterns between more proficient and less proficient students. Identifying the patterns of more proficient ones can give teachers clues to ways to improve less proficient students' language learning.

\section{E. Strategy Instruction Models}

As discussed above, several researchers have identified the differences in the ways more proficient and less proficient students apply strategies to learn languages (Rubin, 1975; Griffiths, 2004; Lightbown \& Spada, 2005). Based on the results of those researchers, others have attempted to create instruction models of strategy use with the aim of helping less proficient students improve their language skills. Two most popular instruction models are the one proposed by Oxford (1990) and another one introduced by O'Malley and Chamot (1990). The latter one is known as the Cognitive Academic Language Learning Approach (CALLA).

The strength of the CALLA is that, unlike Oxford's (1990) model, it is intended for instruction of not only learning strategies, but also content knowledge. It is therefore highly applicable in courses where English is taught for specific purposes (ESP), such as business English or medical English. In those ESP courses, students are exposed to a very rich vocabulary resource related to a particular content subject, and they are required to apply some of their content knowledge in the courses as well. When compared with Oxford's (1990) model, it can be seen that whereas Oxford 
(1990) proposed a full strategy training model for the long-term training process, O’Malley and Chamot (1990) focused mainly on the conduct of an individual training lesson.

In conclusion, the combination of both models would create a more comprehensive training model for the current research.

\section{F. Investigation into Explicit Listening Strategy Instructions}

Recent studies into the effects of explicit listening strategy instruction have been conducted in different contexts and with a wide range of participants, from high school students to college students.

Carrier (2003) is among the minority of researchers who attempted to provide explicit strategies instructions to ESL high school students. The participants in her research consisted of seven high school ESL learners in the United States. The research had a pre- and posttest experimental design. LS instructions were given explicitly to the students in fifteen 20 to 30-minute sessions over the period of six weeks. Revision of the previously taught strategies was an important feature of the intervention. Statistical analysis revealed a significant difference between the mean scores of the pretest and posttest, which enabled Carrier (2003) to conclude that the intervention did help to boost ESL high school students' listening ability and note-taking ability.

Vandergrift and Tafaghodtari (2010) conducted a study to examine the impacts of explicit strategy instructions on learners who were learning French as a second language. The researchers only focused on introducing metacognitive strategies, 106 participants were divided into experimental group $(n=59)$ and control group $(n=47)$. Statistical analysis of posttest scores indicated that participants in the experimental group did outperform those in the control group. The researchers also discovered that low-proficient learners in the experimental group showed "greater gains" (p. 470) than the high-proficient ones.

In Asia, there are two recent studies into explicit listening strategies by Soubouti and Amiri (2014) and Sotoudeh (2013). Both studies employed an experimental pre- and posttest design with quantitative analysis methods. While Sobouti and Amiri (2014) sought evidence of improvement in students' comprehension of news videotexts after giving them training in listening strategies, Sotoudeh (2013) targeted at investigating effects on not only students' listening comprehension but also their strategy use. He found that the course he was teaching was effective in improving students' listening comprehension. He also observed an increase in students' use of listening strategies after the treatment. Sobouti and Amiri (2014) found sound statistical evidence of the positive effect of explicit LS instructions on students' LC, which is in line with some of the findings of Sotoudeh (2013). The findings of Sotoudeh (2013) and Sobouti and Amiri (2014) were in keeping with those found by Carrier (2003) as reviewed above.

Cross (2009) investigated the impacts of LS instructions on Japanese EFL advanced learners' comprehension of news videotext. His study had a quasi-experimental design with eight learners in the control group and seven learners in the experimental group. The difference between two groups in the posttest scores was not significant. A strength in Cross's (2009) study, though, is that he also employed some qualitative methods to collect data. Specifically, he used pretreatment interviews and questionnaires to explore learners' news viewing habits and their approaches to comprehending news videotexts. The analysis of qualitative data helped to inform Cross (2009) when he designed the treatment.

Guan's (2014) recently conducted a study to investigate the influences of a strategy-based approach to teaching listening on ESL students at Community College in California. Her study took into consideration the weaknesses of previous researchers on the strategy approach to teaching listening and made a lot of improvement. The participants, consisting of 52 ESL community college students, were organized into the treatment groups $(n=30)$ and control group $(n=22)$. Guan combined both quantitative methods to measure the improvements of students' listening comprehension through test scores, and qualitative methods to gain insights into students' perceptions of the instructions of listening strategies. Both types of data were collected and analyzed simultaneously. The intervention was carefully planned based on the analysis of the needs of the students. Qualitative data were collected through interviews, observations or background surveys. There were six students taking part in the post-intervention interviews, and six observations were carried out in the treatment class before the intervention. It was found that students held some very positive perceptions about the usefulness of listening strategies. Their patterns of strategy use also changed throughout the course of the project. Quantitative data were collected to measure the effects of explicit LS instructions on students' LC. The same test was used for pre- and post-test, and an independent t-test analysis showed that there was a significant difference between the mean gain scores of the control and treatment groups with $p=0.012$, which enabled the researcher to conclude that the explicit LS instructions improved LC of students in the treatment group. One minor weakness of Guan's (2014) study is that the same test was used for pretest and posttest. Test and retest effects could be minimized if two different tests of the same format and level were used. Nevertheless, the results of Guan's (2014) study indicated some very positive changes in students' listening comprehension and the way they approached listening tasks.

In summary, quite a thick body of research has been conducted on LS instructions in different contexts. The researchers are in agreement that LS instructions are, to a certain extent, beneficial to the teaching and learning of listening. They also share the same ideas about conducting further studies with participants in different age groups, or into strategy instructions of different skills, such as reading, speaking and writing. Nevertheless, the issue of providing explicit listening strategy instructions as a means to enhance students' listening comprehension is still insufficiently investigated. There remains the lack of research on the combination of explicit introduction of listening strategy and 
sub-skills. The only attempt to investigate the sub-skill approach to teaching listening ever recorded was by Daly (2006, cited in Field, 2008). Moreover, much of the research into explicit strategy instructions has a quantitative approach, without extensive qualitative data to explore students' engagement with this approach to teaching listening. In particular, applying a sub-skill and strategy-integrated listening syllabus is still under-researched in the context of Vietnam. Therefore, a study to investigate the effects of explicit sub-skill and strategy instructions on Vietnamese EFL students' listening comprehension would be of some contribution to teaching of listening in the future.

\section{METHODOLOGY}

\section{A. Participants}

The participants were 20 first-year university students majoring in Business English. At the time this study was conducted, the participants were taking the course English for Business Purposes $2 \mathrm{~A}$. To be qualified for 2A, students had to pass the pre-requisite course 1A, of which the final test was at level B1+ in the CEFR. By the end of the course 2A, students were expected to develop their language proficiency to level B2 in the CEFR.

In their high schools, those students had plenty of practice in reading, as well as grammar and vocabulary, so students had already possessed some reading strategies and sub-skills. Thus, in the teacher-researcher's observation, students did not have much difficulty with their listening skills.

It is also noteworthy that each participant in this research was assigned a pseudonym, which was used whenever he/she was cited in this paper.

\section{B. Research Design}

This study has an action research design, which is defined in a broad sense as "a small-scale intervention in the functioning of the real world and a close examination of the effects of such intervention" (Cohen \& Manion, 1994, p. 186). According to O'Brien (1998) action research is employed in situations requiring flexibility, involvement of people, and holistic and rapid changes. In an educational context, action research is a type of research carried out by teachers in their classrooms. Burns (2010, p.2) states that in action research, a teacher becomes "an investigator" or "explorer" of his or her personal teaching context while at the same time being one of the participants in it.

Qualitative methods enabled the researcher to uncover the "multiple perspectives" (Lodico, Spaulding \& Voegtle, 2010) caused by individual differences emerging throughout the whole process. Specifically, qualitative method was employed in this study in order to gain insights into individual EFL learners' experiences with explicit instructions of listening strategies and sub-skills in listening lessons. Data were collected via three data instruments: semi-structured interviews, narrative frames, and observations. The exploitation of these data collection instruments enabled the researcher to triangulate the data collected to investigate the (1) changes that the intervention brought the participants' listening habits (for example, whether they had the habits of using relevant LS when faced with different listening tasks), and also to explore (2) students' engagement with the new approach to teaching listening, and (3) their perceptions of that approach.

\section{Data Collection Instruments}

Semi-structured individual interviews were conducted at the end of the eight-week intervention. Participants were invited to voluntarily participate in the interviews. Eleven out of twenty students responded to the invitation and were interviewed separately. All individual interviews with the students were digitally recorded. In addition, the interviewer also made notes of the main points as the interviews took place. Semi-structured interviews made it possible for the researcher to acquire thorough insights into the changes that the intervention brought to the students. Each individual interview lasted about twenty minutes. See the Appendix for the list of interview questions.

Narrative frames were chosen as a data collection instrument in this study because data collected through them yielded useful information immediately after the delivery of each intervention session, which allowed the researcher to make relevant adjustments to the teaching program. Each participant completed a narrative frame after every session to reflect on the teaching and practice of LSs and SSs in the classroom (except for Session 2, when they had to write a short summary of the recording, and Session 8, when some participants attended the post-intervention interviews). There are twenty-one gaps in a frame. In addition, as students just needed to write down short phrases, or choose the option that best suited them, they would have more motivation to complete a narrative frame than writing a long journal entry.

Aspects to be observed consist of students' responses and attitude towards a particular activity in each session, as well as the whole course. Observations yielded a moderate quantity of data to triangulate with those collected from individual interviews and narrative frames. They provided data from another perspective - the teacher-researcher - in comparison with self-reported information in interviews and frames. In addition to serving for research purposes, data from observations also assisted in the process of amending the LS and SS integrated curriculum. Throughout the intervention, detailed field notes were taken by the researcher at the end of each session.

\section{RESULTS}


The qualitative data collected through individual interviews, observations, and narrative frames indicated that the participants experienced positive changes in listening habits after the intervention. However, there were some variations in students' perceptions of the changes. They quoted examples from both academic contexts (inside the classroom formal learning) and social contexts (outside the classroom - informal learning) as evidence of the changes.

\section{A. Changes in the Way Students Approached Listening Comprehension Problems}

One of the changes mentioned by interviewees was related to the ways they approached listening comprehension activities in class. In general, students knew how to apply strategies to overcome the difficulties they encountered instead of just giving up on the listening tasks. For example, Piper said that she had become a strategic listener after the intervention:

... Before this course [LS and SS integrated course], I couldn't catch enough information, or key words, to answer the questions. I missed the questions because I just couldn't figure out much of the speakers said. However, after the course, I think that I listen more strategically and I can answer the questions more correctly (Interview with Piper).

The fact that students became more strategic listeners was reflected in various aspects. First of all, there were selfreported changes in the pre-listening stage. Rather than waiting passively for a recording, students knew how to apply certain strategies to help themselves prepare better for it. For instance, Andrea shared that she was not used to preparing the related vocabulary and background knowledge in advance when faced with a particular listening activity. As a result, she was often confused when she had to listen to long texts, or even when her teacher redesigned new questions for a listening passage she had prepared at home. After the intervention, Andrea stated that she felt more engaged when listening to long passages because she could now capture more main ideas. She learned how to listen more selectively instead of listening unfocusedly to a load of information. Like Andrea, Michelle reported that she "will now try to make full use of the listening time" (Michelle's narrative frame, Session 4) instead of "surrendering" whenever she found "the recording confusing".

In the case of Thuy, prior to the intervention, she could not catch long sentences. However, after the intervention, she could make more sense of long utterances. Another student, Lee, also reported that after the intervention she could keep better track of what speakers were talking about because she had brainstormed the related contextual knowledge by using personal elaboration or academic elaboration before listening. Moreover, she commented that after the course she applied personal elaboration more frequently than in the past.

Amanda also narrated about changes in the way she approached listening comprehension problems after attending the LS and SS integrated course. Before this, Amanda said that she did not apply any strategies when solving listening problems. She simply listened to a recording and tried to answer its accompanying questions one by one, even though she sometimes could not keep up with the pace of the speakers. As a consequence, if she missed a word or a phrase, it was likely that she would miss the whole following part. Now that she had been taught to listen more strategically, she knew she should listen in a more selective way. She reported that after the intervention she could keep better track of what speakers were talking about because she had brainstormed the related contextual knowledge before listening by using personal elaboration or academic elaboration.

Secondly, changes could be seen in while-listening activities, as in the case of Lee, a more proficient student in the class. She acknowledged her weakness, which was her inability to extract specific information from a listening passage. However, after the intervention, she found that this type of task became more manageable. In addition, Lee referred to the headway she made in her listening-for-main-idea sub-skill. Both Lee and Andrea found note-taking a useful strategy. She reported that she usually visualized and mapped the ideas, as "this practice is quicker, because I don't have to write too much." (Interview with Lee).

As for Andrea, she revealed that selective attention was a strategy that "we have applied beforehand, I mean, we sometimes try to focus just on the questions" (Interview with Andrea), but she did not know what it was termed. Nevertheless, she still found the course useful for her because it gave her a more "systematic picture" of all the strategies and sub-skills. She learnt how to combine selective attention with linguistic inferencing to guess the meaning of some unknown words using the surrounding details that she could catch. "At least I can say whether the word means something positive or negative," said Andrea. Another significant finding about Andrea was that she could apply all the strategies taught in the intervention.

Changes in listening habits were also observed outside of the classroom. Some interviewees gave accounts in their daily life as proof of the changes they experienced after the intervention. Specifically, many students agreed that they made progress in everyday listening after applying the strategies and sub-skills they learnt from the course. For example, Amanda described her unsuccessful communication with foreign colleagues in the organization where she was working as a part-time volunteer prior to the intervention:

In the past [before the LS and SS integrated course] I listened very badly. I used to ask my foreign colleagues to repeat at least seven out of ten utterances they made, like "What have you just said?" They had to slow down and then explain clearly to me (Interview with Amanda).

However, in the post-intervention interview, Amanda talked about noticeable improvement in communicating with her foreign colleagues, which was reflected through the reduction in the time she had to ask them to repeat what they said. She managed to do so because she had altered the way she approached listening: 
Instead of focusing solely on verbal cues and trying to catch every word my colleagues said, I tried to listen more selectively, focusing more on key words. I determined the key words by paying more attention to their pitch and intonation, as well as their body language. (Interview with Amanda)

As a result of changes in the way they approached listening tasks, participants were able to improve their listening competence. For example, Susan self-assessed that her listening comprehension skill had improved "a little" after the eight-week intervention, and mostly quoted evidence from outside the classroom. She was the only participant who used percentage to illustrate her point of how she improved after the intervention. She stated that before the intervention, if she watched a foreign film (in English) without subtitles, she would struggle, and could comprehend only about $30 \%$ to $50 \%$ of what was said. However, throughout the course she found out that there had been an increase in her comprehension of the films she viewed.

\section{B. Changes in the Way Students Approached Lexical Problems When Listening}

Prior to the intervention, students were very confused when they came across new words in listening passages. For example, Amanda mentioned her two reactions when coming across new words in the listening process before the intervention: she either ignored them, or became so obsessed with them that she missed other parts in the listening passage. Such passive reactions had a bad effect on students' listening comprehension. However, after receiving the intervention, students approached new lexical items in a more strategic way. On the whole, students tended to utilize inferencing strategies to get the meaning of new words in the recording. In order to make an informed guess, some might use the context surrounding the words (linguistic inferencing) while others resorted to paralinguistic or extralinguistic clues such as intonation or body language (paralinguistic inferencing and extralinguistic inferencing).

An example of a student who made use of linguistic inferencing to figure out the meaning of new words is Piper. She explained how she utilized this strategy in the excerpt from her interview below:

Previously, I used to be very confused when coming across new words in listening. However, after being taught about linguistic inferencing, I began to rely on the words surrounding it an unidentified word to guess its meaning (Interview with Piper).

Amanda and Andrea are two students who applied extralinguistic and paralinguistic inferencing when encountering new words. Amanda shared how she made use of repetition, voice inferencing and paralinguistic inferencing to guess the meaning of new words in the following excerpt:

I would first try to catch the sound of the word and based on that to guess the spelling or the meaning (Interview with Amanda).

Like Amanda, Andrea also made use of repetition to help her catch new words when listening. Andrea provided further explanation about how she used repetition in the following excerpt:

[...] Some new words are not actually new, it's just that we are used to different, or even wrong, pronunciation of them, and therefore, had difficulty in understanding them. When I repeat after the speakers, I can get a closer interaction with the new words and as a result find it easier to grasp them (Interview with Andrea).

One noteworthy fact emerging from the interview with Andrea and Amada is that one of the ways to enhance the quality of applying inferencing strategies is to repeat after the speakers when listening. As explained by the students, this would help them to catch the spelling of the word and thus increase the chance of understanding it.

\section{Changes in the Way Students Approached Pronunciation and Intonation Problems}

In addition to helping students form positive habits in approaching listening comprehension problems and lexical problems, the intervention also infused in students' good habits in dealing with pronunciation and intonation problems. For example, during the interview, Andrea made a reference to the fact that some English pronunciation features, such as sound linkage, assimilation, and elision, does not exist in Vietnamese. As a result, she often had difficulties listening to people speaking in outside-classroom situations prior to the intervention. She even considered listening to native English speakers a "daunting task". Nevertheless, after attending the eight-week intervention, Andrea said that she could make more sense of what the actors were talking about.

Other students also shared their experience with the learnt LS outside the classroom to deal with pronunciationrelated problems. Lee said that she practiced strategies related to visuals (for example, paralinguistic inferencing or imagery) more when she was using English to communicate in real life. She believed that those strategies that she acquired throughout the intervention would enable her to overcome pronunciation difficulties.

In Amanda's opinion, voice inferencing was the most practical strategy for communication. She did not use to pay much attention to the attitude, or the feeling of the speakers, because she only tried to catch every word articulated. However, after the intervention she took more notice of how the speakers vary their pitch when communicating to show their opinions or attitudes. In addition to voice inferencing, Amanda was fond of repetition because it helped her to correct her pronunciation. Similar to Amanda, Hannah, Susan, and Ann also liked repetition. Hannah explained that the strategy helped her understand the text better as she repeated along with what the speakers were saying selectively.

In summary, it can be seen that the intervention managed to create various changes in students' listening habits, including how they approached listening comprehension problems, lexical problems, and pronunciation problems. 
Throughout the interviews, the participants explained how they found some strategies more applicable than others. In general, students tended to find metacognitive strategies (selective attention, directed attention) and inferencing strategies more manageable than cognitive strategies. Within the category of cognitive strategies, students also preferred inferencing and elaboration strategies to summarization and note-taking strategies. Details of students' interviews are presented below.

Amanda expressed her liking for all the strategies taught throughout the course, but commented that she was particularly impressed by voice inferencing because this strategy was "easy to remember and easy to apply" (Interview with Amanda, 2015). As for Piper, the strategies that she found most useful were linguistic inferencing, directed attention, and comprehension monitoring, which were all metacognitive strategies. She gave further explanation of how she employed those strategies in the excerpt from her interview below:

Directed attention shows me how to base on specific details to get the overall meaning. Comprehension monitoring is also very useful during the lesson because with regular checks we know that we are going in the right way, and therefore, become more confident (Interview with Piper).

When asked about the strategies that she did not find useful during the course, her answer was note-taking strategy. She justified her opinion by describing her experience when employing note-taking strategy in solving listening comprehension problems:

The problem with me when applying note-taking strategy is that I note down the trivial details instead of the main ideas. As a result, when I go through the notes again, I can't understand much and can't choose the correct answers (Interview with Piper).

Similar to Piper, Michelle and Thuy also found note-taking less applicable in their situations because they could not catch up with the speed of the recording and jotting ideas down at the same time. Thuy reported that she could not do two tasks simultaneously, at least for the time being. She attributed this to her inability to write in shorthand. She said:

I don't feel very optimistic about my note-taking skill. Sometimes when I manage to note the first point then I would forget the second point. I just couldn't catch up with the speed at which the speakers communicate (Interview with Thuy, 2015).

The three students above viewed summarization as a strategy they could not make much use of. They linked their failure to take relevant notes to their inability to make effect summaries. Thuy also blamed her poor note-taking skill for her failure to use linguistic inferencing and substitution.

It is worth noting that, although Thuy found summarizing hard to apply, she believed that making summaries was a useful strategy when used appropriately, especially for long listening passages. When asked about the strategies that helped her make headway in listening comprehension, Thuy gave the answer of directed attention and voice inferencing. She elaborated that directed attention taught her to stay focused during the time she listened to the recording, and with voice inferencing she could make more sense of the audio input as she relied on not only the verbal cues but also nonverbal cues like intonation. She also found the repetition a useful strategy in that it enabled her to gain deeper insights and it gave her a chance to look at a transcript again. Elaboration strategies (personal, academic and world) helped Thuy to prepare a better mindset for the activity by predicting the related language.

Andrea, the more proficient student, had a quite contrasting opinion with Piper's and Michelle's regarding the usefulness of summarization. She said:

I think this strategy [summarizing strategy] is a fairly interesting one because if we can catch the main idea, we had better note it down or else we will forget it. This strategy is not very compatible with test practice lessons, but it is very good for general practice in listening skill (Interview with Andrea).

During the interview Lee was the only student who gave a very detailed account of her strategy usage. She stated that she would start by using personal elaboration to embellish on what was already given in the instructions of the task, or the task itself, so that she could be in a more active stance when listening. After that, she intended to use directed attention to catch the general ideas and finally selective attention to grasp specific information. In the individual interview, Lee quoted her performance in two achievement listening tests as proof of her improvement after the intervention. Lee was a student who regularly took notes to aid her listening process. During the sessions, the researcher could observe that she always prepared a sheet of blank paper for jotting down the ideas from the recording. The way she organized her notes is described in the following excerpt from observation field notes of Session 3:

...Lee is using another piece of paper to take notes of the content of the listening passage - what she has done before, even in the achievements. [...] [after a while] The notes are very well-organized with arrows and symbols to illustrate the relationships among main points (Observation notes, Session 3).

An avid user of note-taking strategy as she was, Lee still held some reservations when employing this strategy. She shared that sometimes the information she managed to note down did not match what was needed because she was misled by the prompts of the tasks. She continued by giving her methods to alleviate the situation: she intended to enrich her vocabulary knowledge. She believed by doing so, she would be able to apply linguistic inferencing more effectively. Lee was also keen on using summarization, thinking that it would enable her to gain deeper understanding of what she heard, and develop her substitution strategy. Regarding the least applicable strategy, Lee mentioned repetition because she thought that it did not suit her "present purposes".

E. Students' Suggestions for Improvement 
Regarding what could be done to improve the course, many students made suggestions about approaches to conducting the listening sessions. Specifically, their suggestions clustered around two main aspects: (1) ways to set and organize the listening tasks; and (2) the amount of time spent on each strategy.

Firstly, with reference to the arrangements of the listening tasks, Heidi suggested in her Narrative Frame of Session 4 that the teacher should introduce easy exercises first, and more challenging ones later, so as not to demotivate the learners. Another student, Piper, proposed that the teacher should let the students fend for themselves when faced with a listening task to figure out which strategies to use, before informing them which strategies would be most suitable. Piper shared:

...The teacher can design an exercise that does not state in advance which strategies would be the most suitable to use so that the students can analyze for themselves which strategies would work best here (Interview with Piper).

Still about the listening tasks, Lee suggested that the teacher "use the listening material which may arouse our interest" (Lee's Narrative Frame, Session 1). Helen provided more details about what exactly would "arouse her interest" when suggesting that the teacher should include "more videotexts on the topic of economics or interesting presentation" (Helen's Narrative Frame, Session 4). Sharing the same opinion, Tara gave examples of listening to talks about business strategies by famous economists.

Ann expressed her satisfaction with the number of strategies and sub-skills taught during the intervention, but recommended that the teacher should set more tasks for the students to practice using the strategies at home. She thought that there could be some homework checking activities, but the scores should be kept only for reference purposes, not as a component of the official marking scheme. Susan also shared the ideas of setting home assignments, saying that she was very much keen on receiving homework. Amanda thought that teachers should choose more videos when looking for materials. She believed that the videos would captivate learners' attention more than audios. Lee recommended using short listening passages instead of long ones in class to sustain students' attention. In addition, some students expressed their wish to have the transcripts of the audio texts in the narrative frames to practice some strategies like repetition at home (e.g Trisha's Narrative Frame Session 4).

Secondly, concerning time allotment for each strategy, Andrea suggested that there should be two consecutive sessions for each strategy because she found it rather difficult to get accustomed to a particular strategy right after each session. As for Amanda, she believed that the current time slot was enough for the teacher to cover the main point. What was essential, according to her, was that students practice applying those strategies more at home. After pinpointing fatigue as a factor that affected students' concentration on the lessons, Amanda also proposed that students have more breaks.

It was worth noting that several students' suggestions in the first sessions had been taken into consideration and applied in the following sessions as students' comments on the implementation of the sessions were collected regularly through the use of narrative frames.

\section{Discussion}

The current qualitative study aims to examine the effects of explicit listening strategy and sub-skill instructions on EFL learners' listening habits. On the whole, the three instruments, observations, individual interviews, and narratives frames enabled the researcher to collect rich data to answer the research questions.

Regarding the first research questions, several changes in students' listening habits emerged in the thematic analysis. Firstly, there were changes in students' patterns of strategy use. The participants were able to broaden the range of listening strategies to deal with listening comprehension problems, and at the same time, improve those they had before. They also knew to combine several strategies to solve a task. Those findings were in line with what Guan (2014) reported in her study.

The intervention also helped to increase students' awareness of strategies. The interview results showed that students had practiced some strategies, such as selective attention and directed attention prior to the intervention, but as discussed above, they used those strategies in a random way. Moreover, many of the interviewees admitted not knowing how to listen in the right way before the intervention. This was reflected through the fact that they often failed to comprehend an aural text because of being too preoccupied with a single missing part. The intervention provided students with a more comprehensive range of listening strategies and sub-skills, which paved the way for them to develop metacognitive strategies like planning or monitoring.

In addition, as revealed during the interviews, the participants experienced some positive changes in their listening comprehension after the intervention as a result of changes in listening habits. Many students reported that they could make more sense of the audios and videos they listened to in class, as well as the entertainment programs they saw in real life. Some interviewees even provided some quantitative estimation of the changes in their listening comprehension. These findings converged with the findings from previous studies. For example, Carrier (2003), Soubouti and Amiri (2014), and Sotoudeh (2013) found that the participants in their research did improve some aspects of their listening comprehension through the use of some statistic tests. However, the current study was able to generate more detailed explanation for students' improvement in listening habits.

The LS and SS integrated syllabus also helped to improve students' self-confidence in their listening ability. As presented in the findings, prior to the intervention, many students felt quite insecure and uncomfortable during listening 
time because they thought they did not know how to listen. According to Horwitz, Horwitz and Cope (1986), the simultaneity and spontaneity of listening even creates classroom anxiety. Learners frequently cite factors related to listening, such as failure to distinguish sounds and structures of an aural message, as their top concern (Horwitz et al., 1986). However, data from post-intervention interviews revealed that students became more active in listening sessions after they had been equipped with a range of different listening strategies and sub-skills. Students even shared their plan of utilizing strategies in the future to aid their real-life listening and language learning. Although it is worth noting that self-confidence is very difficult to measure precisely due to the great variation in the way students perceive their confidence level (Siegel, 2012), the improvement in self-confidence reported in post-intervention interviews still indicates promising effects of the strategy and sub-skill approach to teaching listening.

In summary, it could be seen that participants in the study reacted quite positively to this LS and approach. A lot of them have intentions of applying the strategies they gain from this course in not only English, but also other content subjects.

\section{CONCLUSION}

\section{A. Summary of Findings and Conclusion}

The purpose of this study was to gain deeper insights into the effects of explicit instructions of strategies on developing and enhancing students' positive listening habits. Data collected through narrative frames, observations, and individual interviews were thematically analyzed, and several significant findings can be summarized as follows:

Firstly, the intervention succeeded in creating changes in students' listening habits both inside and outside the classroom. The participants became more active in the listening process: they could apply knowledge about listening strategies and sub-skills in aiding their listening. In addition, they were able to broaden the range of LS to deal with listening comprehension problems, and at the same time, improve those that they had before the intervention. They also knew to combine several strategies at a time to solve listening comprehension problems. As a result of all these changes, they could make more sense of the listening materials in the class, as well as English films or entertainment programs they saw at home.

Secondly, several factors were identified as being able to affect the participants' engagement with the intervention. The first factor was the type of strategies introduced. Other factors affecting their attention during the lessons as reported by the students themselves were: topics of the listening texts, the difficulty levels of the texts, personal health, and classroom environment.

Thirdly, the combination of both LS and SS in the syllabus made it easier for the participants to understand what exactly they had to do when practicing a strategy, and what they could gain afterwards.

In conclusion, the current study has been able to confirm the positive effects of a LS and SS integrated syllabus to teaching listening in the context of Vietnam. Teachers who are still adopting the traditional CA approach in teaching listening, especially to low-proficiency students, should consider resorting to the LS and SS approach so that they actually teach the students to listen instead of just testing their listening skills.

\section{B. Pedagogical Implications}

The findings of the current study lead to several significant pedagogical implications and suggestions for teaching listening. Firstly, explicit LS and SS instructions should be integrated into listening lessons, especially those which are for low-level learners. After the intervention, participants in this study adopted some positive listening habits which helped to improve both their in-class and outside-class listening comprehension. They also interacted quite positively with the intervention, even though for many it was the first time they were exposed to this approach to teaching listening.

Secondly, in order to have an effective listening course, teachers should take into consideration learners' needs, and tailor-make the syllabus for them. There is no such thing as a one-fit-all syllabus. The first step for teachers to take in designing a course is what Field (2008) terms taking a diagnostic approach to teaching listening, before implementing the LS and SS syllabus. Specifically, teachers should start by investigating their students' listening problems, as well as drawbacks of the prescribed materials of the course, and then make appropriate changes, including explicit introductions of strategies and sub-skills. During the implementation of the syllabus, teachers should provide their students with plenty of opportunities to practice listening strategies in both academic and real life contexts (Siegel, 2012).

Thirdly, not only should the strategies and the sub-skills be carefully chosen based on analysis of learners' needs, but they should also be well matched, so that the application of a strategy would make it easier for the learners to master a sub-skill. In addition, the sequence of strategy and sub-skill should not be fixed; instead, it should be flexible in such a way that its components are swappable based on students' needs and their response to the syllabus during the implementation process.

Furthermore, the qualitative data from this study also generated some suggestions for teachers regarding the selection of materials. Ideally, teachers should choose a range of both academic and real-life materials and use not only audio but also videos. The superiority of videos over audios is that they can provide learners with verbal cues and non-verbal cues 
simultaneously. The visuals of videos may help to make the lessons more interesting as they offer students a break from the traditional way of teaching listening with audios. Regarding the combination of visuals and audios, academic and real-life materials, it is recommended that teachers invite native speakers to have a talk in the classroom. Teachers can also adopt English as the main language of instruction to expose their learners to English as much as possible during the lesson. In this case, teachers should employ several techniques when giving instructions in English, like varying intonation, slower or faster speaking speech, to activate the use of such strategies as voice inferencing and extralinguistic inferencing. Of course, teachers may resort to Vietnamese from time to time to make sure that their students fully comprehend the instructions, as one of the primary objectives of the strategy and sub-skill syllabus is to enable students to use LS.

Finally, some simple forms of data collection tools, such as narrative frames or group and individual interviews, should also be designed and implemented throughout the course to investigate learners' comments and feedback on the LS and SS integrated syllabus. Teachers can use information gathered by these tools to make timely amendment to the syllabus if needed.

\section{APPENDIX. INTERVIEW QUESTIONS}

1. In your view, what were the new listening sessions about?

2. Can you describe how you have applied the listening strategies and/or listening sub-skills to aid your listening comprehension?

3. Do you feel your listening competence have gone up, gone down, or stayed the same during this semester? Why?

4. (Give the interviewee a list of all strategies and sub-skills to pick from.) Which strategies and sub-skills do you think are the most useful to you? Why?

5. Which strategies and sub-skills are the least applicable to you? Why?

6. What obstacles have you had so far in applying the strategies and/or sub-skills?

7. What do you think affected the quality of the eight listening sessions? Can you explain how?

8. Can you tell me what you wish that I had taught you? Or what would be a better way to teach you?

9. Do you plan to apply those listening strategies and sub-skills in your future studies? Why or Why not? If yes, please provide an example.

10. Is there anything else you would like to tell me about your experience of this new approach to teaching listening?

\section{REFERENCES}

[1] Anderson, J. (1985). Cognitive psychology and its implication. New York: Freeman.

[2] Berne, J. (2004). Listening comprehension strategies: A review of the literature. Foreign Language Annals, $37,521-533$.

[3] Burns, A. (2010). Doing action research in English language teaching: a guide for practitioner. New York: Routledge

[4] Carrier, K. (2003). Improving high school English language learners' second language listening through strategy instruction. Bilingual Research Journal, 27(3), 383-408.

[5] Cohen, L. \& Manion, L. (1994). Research methods in education $\left(4^{\text {th }}\right.$ ed.). London: Routledge.

[6] Cross, J. (2009). Effects of listening strategy instruction on news videotext comprehension. Language Teaching Research, 13(2), 151-176.

[7] Ellis, R. (1994). The study of second language acquisition. New York, NY: Oxford University Press.

[8] Field, J. (1998). Skills and strategies: Towards a new methodology for listening. ELT Journal, 52(2), 110-118.

[9] Field, J. (2001). The changing face of listening. In J. C. Richards and W. A. Renandya (eds.), Methodology in Language Teaching. Cambridge: Cambridge University Press, 242-247.

[10] Field, J. (2008). Listening in the language classroom. Cambridge: Cambridge University Press

[11] Flowerdew, J \& Miller, L. (2005). Second language listening: theory and practice. New York: Cambridge University Press.

[12] Goh, C. (1998). How ESL learners with different listening abilities use comprehension strategies and tactics. Language Teaching Research, 2(2), 124-147.

[13] Goh, C. (2010). Listening as process: Learning activities for self-appraisal and self-regulation. In N. Harwood (Ed.), English language teaching materials: Theory and Practice, 179-206. Cambridge: Cambridge University Press.

[14] Graham, S. \& Macaro, E. (2008). Strategy instruction in listening for lower-intermediate learners of French. Language learning, 58(4), 747-783.

[15] Guan, Y. (2014). The effects of explicit listening strategy instruction on the listening comprehension of English as Second Language (ESL) community college students. University of San Francisco: Doctoral Dissertations.

[16] Hedge, T. (2000). Teaching and learning in the language classroom. New York: Oxford University Press.

[17] Helgesen, M. (2003). Listening. In D. Nunan (Ed.), Practical english language teaching (pp. 24-46). Singapore: McGraw-Hill.

[18] Horwitz, E. K., Horwitz, M. B., \& Cope, J. A. (1986). Foreign language classroom anxiety. The Modern Language Journal, 70(2), 125-132.

[19] Lightbown, P. M. \& Spada, N. (2005). How languages are learned. Oxford: Oxford University Press

[20] Lodico, M., Spaulding, D., \& Voegtle, K. (2010). Methods in educational research: From theory to practice. San Francisco, CA: John Wiley \& Sons, Inc.

[21] Lynch, T. (2009). Teaching second language listening. Oxford: Oxford University Press.

[22] Mendelsohn, D. (2006). Learning how to listen using listening strategies. In Current trends in the development and teaching of the four language skills, ed. E. Uso Juan and A. Martinez-Flor, 75-89. Berlin: Mouton de Gruyter. 
[23] Naiman, N., Frohlich, M., Stern, H. and Todesco, A. (1978). The good language learner. Toronto, Ontario: Ontario Institute for Studies in Education.

[24] O'Brien, R. (1998). An overview of the methodological approach of action research. Retrieved March 7, 2014 from: http://www.web.ca/ robrien/papers/arfinal.html.

[25] O’Malley, J. M. \& Chamot, A. U. (1990). Learning strategies in second language acquisition. Cambridge: Cambridge University Press.

[26] Oxford, R. L. (1990). Language learning strategies: What every teacher should know. Boston: Heinle \& Heinle Publishers.

[27] Peterson, P. W. (2001). Skills and strategies for proficient listening. In M. Celce-Murcia (Ed.) Teaching English as a second or foreign language $\left(3^{\text {rd }}\right.$ edition). Boston: Heinle \& Heinle.

[28] Renandya, W. (2012). The tape is too fast. Modern English Teacher, 21(3), 5-9.

[29] Rost, M. (1990). Listening in language learning. London: Longman

[30] Rubin, J. (1975). What the "good language learner" can teach us. TESOL Quarterly, 9(1), 41-51.

[31] Rubin, J. (1994). A review of second language listening comprehension research. The Modern Language Journal, 78(ii), 199221.

[32] Siegel, J. (2013). Second language learners' perceptions of listening strategy instruction. Innovation in Language Learning and Teaching, 7(1), 1-18.

[33] Sobouti, F. \& Amiri, M. (2014). The impact of listening strategy instruction on the improvement of Iranian intermediate EFL learners' comprehension of news videotexts. Academic Research International, 5(2), 334-344.

[34] Sotoudeh, N. (2013). Effect of listening strategy training on Iranian EFL learners' listening comprehension and use of strategies. International Journal of Linguistics, 5(6), 171-193.

[35] Thornbury, S. (2006). An A-Z of ELT: a dictionary of terms and concepts. Oxford: Macmillan Publishers Limited.

[36] Vandergrift, L. (1997). The strategies of second language (French) listeners: A descriptive study. Foreign Language Annals, 30(3), 387-409.

[37] Vandergrift, L. (2004). Listening to learn or learning to listen?. Annual review of applied linguistics, 24, 3-25.

[38] Vandergrift, L. (2007). Recent developments in second and foreign language listening comprehension research. Language teaching, 40, 191-210.

[39] Vandergrift, L. \& Tafaghodtari, M. (2010). Teaching L2 learners how to listen does make a difference: an empirical study. Language Learning, 60(2), 470-497.

Hoang Huy Nguyen is a lecturer at University of Languages and International Studies, Vietnam National University (ULIS VNU), Hanoi. He received his BA in English Language Teacher Education from ULIS, VNU (Honors Program), and then got this MA in TESOL from College of Education, Victoria University, Australia. He has given presentations at several national and international conferences on ELT. His research interests include teaching methodology, learning strategies, learning theory, and ICT in language teaching and learning. 